\title{
MYCOVERSILIN, A NEW ANTIFUNGAL ANTIBIOTIC
}

\section{MECHANISM OF ACTION ON A FILAMENTOUS FUNGUS TRICHOPHYTON RUBRUM}

\author{
H. K. Kole and S. K. Bose* \\ Department of Biochemistry, University College of Science, \\ 35, Ballygunge Circular Road, Calcutta 700 019, India
}

(Received for publication January 19, 1984)

\begin{abstract}
Mycoversilin is active against filamentous fungi, being specifically inhibitory to Trichophyton rubrum, minimum inhibitory concentration being $15 \mu \mathrm{g} / \mathrm{ml}$. Mycoversilin inhibits sporulation to the extent of $28.5 \%$ even at the growth inhibitory concentration whereas inhibition of spore germination requires higher concentration. It has no effect on radial growth. Further it shows no action either on the release of UV absorbing materials or on the respiration of T. rubrum. However, the antibiotic inhibits in vivo synthesis of protein fairly strongly, DNA moderately and RNA slightly at the minimum inhibitory concentration. Cell-free protein synthesis is also strongly inhibited, the site of action being the inhibition of leucyltRNA formation by the antibiotic which has no action on leucine activation.
\end{abstract}

Mycoversilin (Fig. 1) is a new antifungal antibiotic isolated in this laboratory from the culture filtrate of Aspergillus versicolor $\left(\mathrm{N}_{5}\right)_{17}{ }^{1,2,3)}$. The antibiotic is specifically active against filamentous fungus Trichophyton rubrum, a skin pathogen. In the present paper we are presenting the results of our studies on the mechanism of action of mycoversilin on T. rubrum.
Fig. 1. Chemical structure of mycoversilin.<smiles></smiles>

\section{Materials and Methods}

\section{Chemicals}

$\mathrm{L}-\left[U-{ }^{14} \mathrm{C}\right]$ Leucine with a specific activity of $240 \mathrm{mCi} / \mathrm{mmol},\left[{ }^{14} \mathrm{C}\right]$ thymine $18.8 \mathrm{mCi} / \mathrm{mmol},\left[{ }^{14} \mathrm{C}\right]-$ phenylalanine $432 \mathrm{mCi} / \mathrm{mmol},\left[2-{ }^{14} \mathrm{C}\right]$ uracil $54 \mathrm{mCi} / \mathrm{mmol}$ and sodium $\left[{ }^{32} \mathrm{P}\right]$ pyrophosphate $5 \mathrm{mCi} / \mathrm{mmol}$ were purchased from Bhaba Atomic Research Centre, Bombay, India. L- $\left[{ }^{14} \mathrm{C}\right]$ Leucine, $\left[{ }^{14} \mathrm{C}\right]$ thymine and $\left[2{ }^{14} \mathrm{C}\right]$ uracil were diluted with respective carrier substrates to give a $1 \mathrm{~mm}, 5 \mathrm{mCi} / \mathrm{mmol}$ solution. Adenosine triphosphate (ATP), guanosine triphosphate (GTP), phosphoenol pyruvate (PEP), polyuridylic acid (polyU), pyruvate kinase, spermine tetrahydrochloride, dithiothreitol (DTT), uracil, thymine, leucine, bovine serum albumin (BSA), 2,5-diphenyloxazole (PPO) and phenyloxazolylphenyloxazolylphenyl(POPOP) were purchased from Sigma. All other chemicals were of reagent grade.

\section{Organisms and Growth Media}

All our studies were done with the sensitive organism T. rubrum, obtained from the School of Tropical Medicine, Calcutta, India. The organism was maintained on Sabouraud agar slants at $28^{\circ} \mathrm{C}$. Sabouraud agar medium was used for plating and harvesting of spores whereas Sabouraud broth for growth and harvesting of mycelium. For incorporation studies with intact cells of T. rubrum, a synthetic medium containing glucose $4 \%$, monosodium glutamate $1 \%, \mathrm{KH}_{2} \mathrm{PO}_{4} 0.05 \%, \mathrm{MgSO}_{4} \cdot 7 \mathrm{H}_{2} \mathrm{O}$ $0.05 \%$ and $\mathrm{ZnSO}_{4} \cdot 7 \mathrm{H}_{2} \mathrm{O} 0.001 \%$, pH 5.5 was used which was subsequently named nitrate free glutamate containing Czapek-Dox medium. 
Mycoversilin

Mycoversilin was used as solution in $95 \%$ ethanol. The final concentration of ethanol in the assay mixtures was kept lower than or equal to $0.7 \%$.

Buffers Used

Buffer $\mathrm{A}, \mathrm{B}$ and $\mathrm{C}$ contained the following ingredients:

Buffer A: $50 \mathrm{~mm}$ Tris- $\mathrm{HCl}$, pH 8.0 containing $5 \mathrm{~mm}$ magnesium acetate, $10 \mathrm{~mm} \mathrm{KCl}, 10 \mathrm{~mm}$ DTT and 0.5 mм spermine tetrahydrochloride.

Buffer B: $10 \mathrm{~mm}$ Tris- $\mathrm{HCl}$, pH 7.5 containing $0.3 \mathrm{~m}$ sucrose, $5 \mathrm{~mm}$ magnesium acetate and $1 \mathrm{~mm}$ DTT.

Buffer C: $20 \mathrm{~mm}$ Tris- $\mathrm{HCl}, \mathrm{pH} 7.5$ containing $0.1 \mathrm{~m}$ ammonium chloride, 5 mм magnesium acetate and $1 \mathrm{~mm}$ DTT.

Minimum Inhibitory Concentration (MIC)

Standard serial agar plate dilution assay was used to determine the MIC. The MIC was read after 72 hours of incubation at $32^{\circ} \mathrm{C}$.

Preparation of Spore Suspension of T. rubrum

A 21 days old slant of $T$. rubrum was washed thoroughly with distilled water. The washings were filtered through cotton to remove mycelium fragments. The spore suspension so obtained was diluted to give an absorbance of 30 Klett units at $660 \mathrm{~nm}$.

Determination of Growth Curve

Effect of mycoversilin on the growth of T. rubrum was followed by determining the mycelial dry weight, grown under shake condition at $32^{\circ} \mathrm{C}$.

Determination of Fungistatic or Fungicidal Action

Spore suspension $(0.3 \mathrm{ml})$ was inoculated into $10 \mathrm{ml}$ of Sabouraud broth containing desired concentrations of the antibiotic or alcohol and incubated at $32^{\circ} \mathrm{C}$ under shake condition. After desired intervals the growth of T. rubrum was filtered, washed with distilled water and resuspended in $10 \mathrm{ml}$ of fresh Sabouraud broth and incubated further at $32^{\circ} \mathrm{C}$ for 48 hours to observe if growth had occurred.

Effect of Mycoversilin on Radial Growth, Spore Germination and Sporulation

Radial Growth: The method described by NENE ${ }^{4}$ was followed. Discs of inoculum $(6 \mathrm{~mm})$ cut out of the periphery of actively growing colonies of the test fungus were used.

Spore Germination: Spore germination was studied following the method of Bose ${ }^{5)}$. Number of germinated spores on a microscopic slide were counted under AO phase contrast microscope after 44 hours of incubation in a moist chamber at $32^{\circ} \mathrm{C}$.

Sporulation: The test fungus was allowed to grow in Sabouraud agar medium in presence of the antibiotic. After 28 days of incubation spores from discs $(14 \mathrm{~mm})$ of $T$. rubrum growth were harvested into $8 \mathrm{ml}$ of distilled water, filtered and the number counted using NeUbaueR's counting chamber.

Effect of Mycoversilin on the Release of UV Absorbing Substances

The method used was essentially the same as described by HALDER et al. ${ }^{8)}$. T. rubrum cells in early logarithmic phase $(10 \mathrm{mg}$ wet weight) were suspended in $10 \mathrm{ml}$ of $0.1 \mathrm{M}$ phosphate buffer, $\mathrm{pH}$ 7.0. The antibiotic was added and the mixture shaken at $37^{\circ} \mathrm{C}$ for 24 hours. The mycelia were then filtered and the absorbancy readings at $260 \mathrm{~nm}$ and $280 \mathrm{~nm}$ of the supernatants were determined.

Effect of Mycoversilin on the Respiration (Endogenous and Exogenous) of T. rubrum

Respiration was measured in the WARBURG apparatus following the method of HALDER et al. ${ }^{8}$.

Macromolecular Synthesis in the Intact Cells of T. rubrum

Cells were grown to early logarithmic phase in nitrate free glutamate containing Czapek-Dox medium. Radiolabelled precursors were incorporated following the method of SinGH et al. ${ }^{7)}$ for 60 minutes at $30^{\circ} \mathrm{C}$ with 15 minutes preincubation with mycoversilin, and the radioactivity of $10 \%$ cold TCA insoluble material was determined in a liquid scintillation counter using $5 \mathrm{ml}$ of toluene base scintillation counting solution. For protein and RNA synthesis, $1 \mathrm{ml}$ reaction mixture contained $1 \mathrm{mg}$ of cells and $0.1 \mu \mathrm{Ci}\left[{ }^{14} \mathrm{C}\right]$ leucine or $0.1 \mu \mathrm{Ci}\left[2-{ }^{14} \mathrm{C}\right]$ uracil and for DNA synthesis $2 \mathrm{ml}$ reaction mixture 
contained $4 \mathrm{mg}$ of cells and $0.5 \mu \mathrm{Ci}\left[{ }^{14} \mathrm{C}\right]$ thymine.

Preparation of Enzyme for Studying Cell-free Protein Synthesis and Aminoacyl-tRNA Formation

T. rubrum cells grown to early logarithmic phase in Sabouraud broth were used to prepare cellfree extract according to SUGAWARA ${ }^{8)}$ using buffer A for homogenization. The extract was centrifuged at $10,000 \times g$ for 10 minutes, then at $20,000 \times g$ for 20 minutes and again at $20,000 \times g$ for 30 minutes discarding the pellet after each centrifugation. A part of this $20,000 \times g$ supernatant was used as the enzyme source for studying cell-free protein synthesis and the rest was again centrifuged at $105,000 \times g$ for 1.5 hours in an Ultracentrifuge (Beckman). This $105,000 \times g$ supernatant was used as the enzyme source for studying aminoacyl-tRNA formation. Protein content in the supernatant was measured by the method of LowRY et al..$^{\text {g) }}$ using BSA as the standard.

Preparation of pH 5 Enzyme

The pH 5 enzyme from filamentous T. rubrum was prepared following the method of HoAGLAND et al. ${ }^{10)}$ as further modified by STAEHELIN and FALVEY ${ }^{11)}$. T. rubrum early log phase cells in Sabouraud broth were used to prepare cell-free extract according to SUGAWARA ${ }^{8)}$ using buffer B for homogenization. The post-mitochondrial supernatant was prepared by centrifugation of the extract at $20,000 \times g$ for 30 minutes which was then further centrifuged in an Ultracentrifuge (Beckman) at $105,000 \times g$ for 1.5 hours. The supernatant (post-microsomal) was then diluted with two volumes of cold distilled water containing $1 \mathrm{~mm}$ DTT and the $\mathrm{pH}$ was adjusted to $5.1 \sim 5.2$ by dropwise addition of $1 \mathrm{M}$ acetic acid with constant stirring. The precipitate which formed was immediately centrifuged at $20,000 \times g$ for 10 minutes and then dissolved in buffer $\mathrm{C}$. The $\mathrm{pH}$ was adjusted to 7.5 by addition of small amounts of $1 \mathrm{~N} \mathrm{KOH}$. The final volume was approximately $1 \mathrm{ml}$ per $6 \mathrm{ml}$ of post-microsomal supernatant. Traces of insoluble material were removed by centrifugation. Protein content in the $\mathrm{pH} 5$ enzyme fraction was determined by the method of LowRY et al. ${ }^{0)}$

Protein Synthesis in Cell-free System

The $20,000 \times g$ supernatant was used as the enzyme source for studying polyU directed cell-free protein synthesis. Incorporation studies were carried out according to the method of SingH et al. ${ }^{7}$. After incubation at $37^{\circ} \mathrm{C}$ for 30 minutes, one volume of ice cold $10 \%$ TCA was added to terminate the reaction. Tubes were placed in a boiling water bath for 15 minutes. After cooling the insoluble protein fraction was filtered, washed and dried according to SiekeVIIZ's's2) method. Radioactivity on the dried filter papers was counted in a liquid scintillation counter using toluene base scintillation counting solution.

Amino Acid Activation by Amino Acid Dependent Pyrophosphate Exchange Reaction

The $\mathrm{pH} 5$ enzyme was used as the enzyme source for studying leucine dependent activation reaction following the method of Roth and AMES ${ }^{13)}$. The reaction mixture contained in a volume of 500 $\mu$ l: $100 \mathrm{~mm}$ Tris- $\mathrm{HCl}$ pH 7.6, $10 \mathrm{~mm} \mathrm{KF,} 5$ m magnesium chloride, 2 mм DTT, 2 mм ATP, 2 mм leucine, $2 \mathrm{~mm}$ sodium pyrophosphate, ${ }^{32} \mathrm{P}$-labelled sodium pyrophosphate $15 \mu \mathrm{Ci}$, mycoversilin solution or alcohol and pH 5 enzyme ( $1 \mathrm{mg}$ protein). After incubation at $37^{\circ} \mathrm{C}$ for 30 minutes, the reaction was stopped by adding $0.5 \mathrm{ml}$ of ice-cold $10 \%$ TCA containing Norit A $(30 \mathrm{mg} / \mathrm{ml})$ and sodium pyrophosphate $(0.1 \mathrm{mmol})$. After standing for 15 minutes at $0^{\circ} \mathrm{C}$, the mixture was collected by Millipore filtration and the radioactivity was counted in a liquid scintillation counter.

Method of Following Aminoacyl-tRNA Formation in Presence of Mycoversilin

The $105,000 \times g$ supernatant was used as the enzyme source for studying $\left[{ }^{14} \mathrm{C}\right]$ leucyl-tRNA formation by the process as developed by FANGMAN and NEIDHARDT ${ }^{14)}$. The reaction mixture contained in a volume of $500 \mu \mathrm{l}: 50 \mathrm{~mm}$ Tris- $\mathrm{HCl} \mathrm{pH} \mathrm{7.5,} 3.5 \mathrm{~mm}$ magnesium acetate, $7.0 \mathrm{~mm} \mathrm{KCl}, 2 \mathrm{~mm}$ DTT, 0.15 mM GTP, 2 mM ATP, $5 \mathrm{~mm}$ PEP, $25 \mu \mathrm{g}$ pyruvate kinase, $\left[{ }^{14} \mathrm{C}\right]$ leucine $1 \mu \mathrm{Ci}$, mycoversilin solution or alcohol and 105,000 $\times g$ supernatant fraction ( $1 \mathrm{mg}$ protein). After incubating for 20 minutes at $30^{\circ} \mathrm{C}$, the reaction was terminated by addition of $3.5 \mathrm{ml}$ cold $6 \%$ TCA. The acid insoluble precipitate was filtered through glass filter (Whatman GF/C) in the cold $\left(4{ }^{\circ} \mathrm{C}\right.$ ) and washed with $5 \%$ TCA containing $0.5 \%$ of DL- $\left[{ }^{12} \mathrm{C}\right] l$ leucine. The radioactivity on glass filter was counted in a liquid scintillation counter. 


\section{Results}

Effect of Mycoversilin on the Growth of T. rubrum

The minimum inhibitory concentration (MIC) of mycoversilin against $T$. rubrum was found to be $15 \mu \mathrm{g} / \mathrm{ml}$.

Fig. 2 shows that at subinhibitory concentrations the antibiotic had no effect on the growth, while at MIC level it affected the lag period only slightly but maximum growth supportable was very strongly affected. At $20 \mu \mathrm{g} / \mathrm{ml}$, the specific effect was particularly on the lag period which was almost 4 days and the maximum growth supportable was also very adversely affected, being inhibited to $59 \%$ of the control.

\section{Nature of Antifungal Action, Fungistatic or Fungicidal}

The antibiotic was fungistatic at the concentrations of 15,30 and $60 \mu \mathrm{g} / \mathrm{ml}$. It's fungicidal activity was observed only at $120 \mu \mathrm{g} / \mathrm{ml}$ (data not shown).

\section{Effect of Mycoversilin on Radial Growth, Spore \\ Germination and Sporulation of T. rubrum}

It appears from Fig. 3 that mycoversilin had no inhibitory effect on radial growth even at a concentration as high as $300 \mu \mathrm{g} / \mathrm{ml}$. However, it had some inhibitory effect at exceptionally high concentrations viz. $480 \mu \mathrm{g} / \mathrm{ml}$ or $600 \mu \mathrm{g} / \mathrm{ml}$.

The effect of mycoversilin on spore germination was not very marked, inhibition being $16.6 \%$ at the MIC level. However, elevated concentrations of the antibiotic increased the inhibitory effect, which was as high as $91 \%$ at an unusually high concentration viz. $180 \mu \mathrm{g} / \mathrm{ml}$ (Fig. 3).

Fig. 3 also shows that mycoversilin inhibited sporulation strongly, inhibition being $28.5 \%$ at MIC. At $30 \mu \mathrm{g} / \mathrm{ml}$ it inhibited sporulation by $73.7 \%$. With a further increase in concentrations, the degree of inhibition $(\%)$ also increased but slowly.

Fig. 2. Effect of mycoversilin on the growth of $T$. rubrum.

Growth was determined from dry weight of mycelia.

$\bigcirc$ Control, $\square$ mycoversilin $5 \mu \mathrm{g} / \mathrm{ml}, \Delta 10 \mu \mathrm{g} / \mathrm{ml}$,

$$
\text { - } 15 \mu \mathrm{g} / \mathrm{ml}, 20 \mu \mathrm{g} / \mathrm{ml} \text {. }
$$

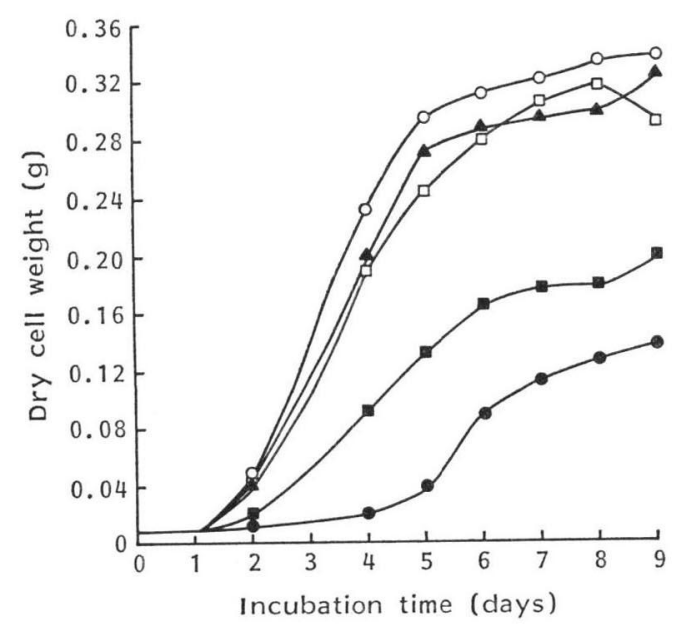

Fig. 3. Effect of mycoversilin on the different stages in the life cycle of $T$. rubrum.

- Sporulation, $\bigcirc$ spore germination, $\Delta$ radial growth.

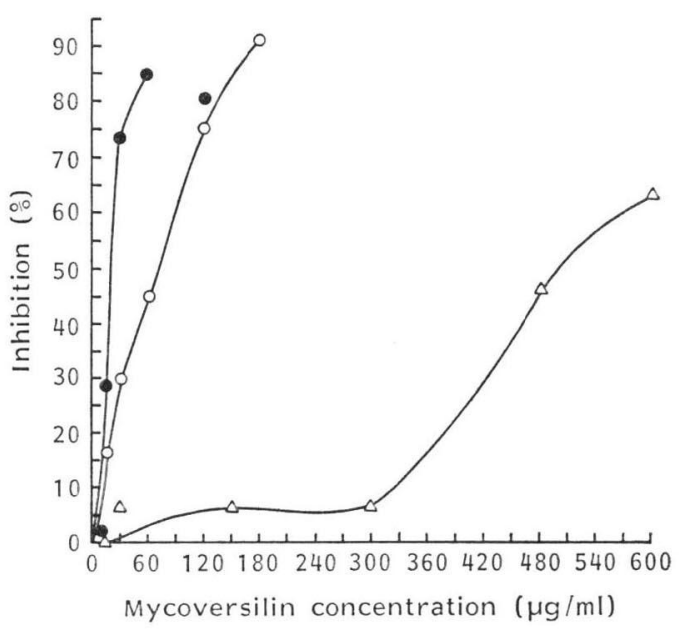


Table 1. Effect of mycoversilin on incorporation of $\mathrm{L}-\left[U-{ }^{14} \mathrm{C}\right]$ leucine, $\left[2-{ }^{14} \mathrm{C}\right]$ uracil and $\left[2-{ }^{14} \mathrm{C}\right]$ thymine into the protein, RNA and DNA of T. rubrum.

\begin{tabular}{|c|c|c|c|c|c|c|}
\hline \multirow{2}{*}{$\begin{array}{l}\text { Mycover- } \\
\text { silin } \\
(\mu \mathrm{g} / \mathrm{ml})\end{array}$} & \multicolumn{2}{|c|}{$\begin{array}{l}\mathrm{L}-\left[U-{ }^{14} \mathrm{C}\right] \text { Leucine incorporation } \\
\text { into protein }\end{array}$} & \multicolumn{2}{|c|}{$\begin{array}{c}{\left[2-{ }^{14} \mathrm{C}\right] \text { Uracil incorporation }} \\
\text { into RNA }\end{array}$} & \multicolumn{2}{|c|}{$\begin{array}{c}{\left[2-{ }^{14} \mathrm{C}\right] \text { Thymine incorporation }} \\
\text { into DNA }\end{array}$} \\
\hline & $\mathrm{cpm} / \mathrm{mg}$ cell & Inhibition $(\%)$ & $\mathrm{cpm} / \mathrm{mg}$ cell & Inhibition $(\%)$ & $\mathrm{cpm} / \mathrm{mg}$ cell & Inhibition $(\%)$ \\
\hline 0 & 8,476 & - & 6,516 & - & 4,690 & - \\
\hline 15 & 4,309 & 49.1 & 5,671 & 13.1 & 3,835 & 18.3 \\
\hline 30 & 3,513 & 58.5 & 5,048 & 22.5 & 2,524 & 46.1 \\
\hline 60 & 2,803 & 67.0 & 4,854 & 25.5 & 2,178 & 53.6 \\
\hline
\end{tabular}

Incubation 1 hour at $30^{\circ} \mathrm{C}$. The mean of triplicate assay of each experiment are presented.

Effect of Mycoversilin on the Release of UV Absorbing Substances

Mycoversilin at any concentrations tested (ranging from $15 \sim 150 \mu \mathrm{g} / \mathrm{ml}$ ) did not cause release of $260 \mathrm{~nm}$ and $280 \mathrm{~nm}$ absorbing materials from mycelia of T. rubrum (data not shown).

\section{Effect of Mycoversilin on Respiration \\ (Endogenous and Exogenous)}

Fig. 4 shows that mycoversilin did not have any effect on respiration both endogenous and exogenous either at MIC or at higher concentrations (viz. $30 \mu \mathrm{g} / \mathrm{ml}$ or $60 \mu \mathrm{g} / \mathrm{ml}$ ).

Effect of Mycoversilin on Macromolecular Synthesis in the

\section{Intact Cells of T. rubrum}

Fig. 4. Effect of mycoversilin on respiration (endogenous and exogenous) of $T$. rubrum.

The reaction mixture in $15-\mathrm{ml}$ WARBURG flask contained $30 \mathrm{mg}$ wet weight of 4 days old mycelium (corresponding to $4.5 \mathrm{mg}$ dry weight), mycoversilin solution or alcohol $0.1 \mathrm{ml}, 0.1 \mathrm{M}$ phosphate buffer $(\mathrm{pH} 7.0) 2.8 \mathrm{ml}$ and water or $0.6 \mathrm{M}$ glucose $0.1 \mathrm{ml}$. Central cup contained $0.20 \mathrm{ml} 20 \% \mathrm{KOH}$ solution. Temp $37^{\circ} \mathrm{C}$. Gas phase air. Incubation period 1 hour.

Control, $\square$ mycoversilin $15 \mu \mathrm{g} / \mathrm{ml}, \quad 30 \mu \mathrm{g} /$ $\mathrm{ml}$, 䟺 $60 \mu \mathrm{g} / \mathrm{ml}$.

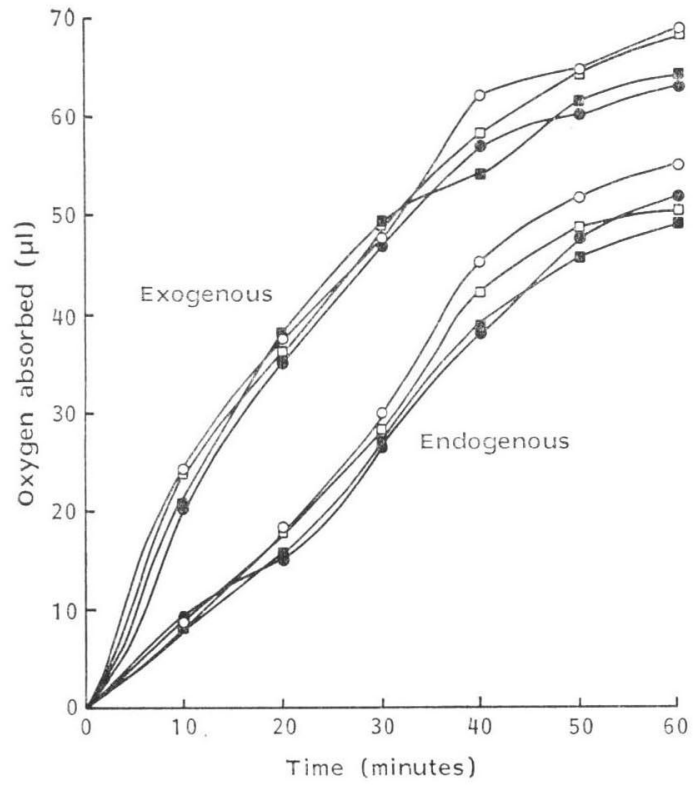

It appears from the results (Table 1 ) that approximately $50 \%$ inhibition of protein and DNA synthesis were observed at antibiotic concentrations $15 \mu \mathrm{g} / \mathrm{ml}$ (MIC) and $30 \mu \mathrm{g} / \mathrm{ml}$ respectively.

Table 2. Effect of mycoversilin on protein synthesis in cell-free system.

\begin{tabular}{lccc}
\hline System & $\begin{array}{c}\text { Mycoversilin } \\
(\mu \mathrm{g} / \mathrm{ml})\end{array}$ & $\begin{array}{c}\text { Phenylalanine } \\
\text { incorporation } \\
(\mathrm{cpm} / \mathrm{mg} \\
\text { protein) }\end{array}$ & $\begin{array}{c}\text { Inhibition } \\
\text { or decrease } \\
(\%)\end{array}$ \\
\hline Complete & 0 & 1,971 & - \\
Complete & 15 & 804 & 59.2 \\
Complete & 30 & 764 & 61.2 \\
Complete & 60 & 625 & 68.3 \\
- PolyU & 0 & 265 & 86.55 \\
- ATP, & 0 & 187 & 90.5 \\
- PEP, & 0 & & \\
- pyruvate & & & \\
kinase & & & \\
- ATP, & 0 & 405 & 79.4 \\
- PEP, & & & \\
- pyruvate & & & \\
kinase & & &
\end{tabular}

Reaction mixture of $500 \mu 1$ contained: $50 \mathrm{~mm}$ Tris$\mathrm{HCl} \mathrm{pH} 7.5,3.5 \mathrm{~mm}$ magnesium acetate, $7.5 \mathrm{~mm} \mathrm{KCl}$, $0.5 \mathrm{~mm}$ spermine tetrahydrochloride, $0.05 \mathrm{~mm}$ DTT, $0.15 \mathrm{~mm}$ GTP, $0.5 \mathrm{~mm}$ ATP, $5 \mathrm{~mm}$ PEP, $\left[{ }^{14} \mathrm{C}\right]$ phenylalanine $0.1 \mu \mathrm{Ci}, 100 \mu \mathrm{g}$ polyU, $25 \mu \mathrm{g}$ pyruvate kinase, mycoversilin solution or alcohol (desired concentrations) and enzyme extract (1 $\mathrm{mg}$ protein).

The mean of triplicate assay are presented. 
Table 3. Effect of mycoversilin on leucine activation.

\begin{tabular}{ccc}
\hline $\begin{array}{c}\text { Mycoversilin } \\
(\mu \mathrm{g} / \mathrm{ml})\end{array}$ & cpm/mg protein & $\begin{array}{c}\text { Inhibition } \\
(\%)\end{array}$ \\
\hline 0 & 27,470 & - \\
10 & 21,508 & 21.7 \\
15 & 21,976 & $20.0^{*}$ \\
25 & 20,117 & 26.7 \\
50 & 20,601 & 25.0 \\
100 & 15,216 & 44.6 \\
\hline
\end{tabular}

Incubation period: 30 minutes at $37^{\circ} \mathrm{C}$.

The mean of triplicate assay are presented.

* This data represents the result of a single experiment, the other two being omitted because of their aberrant values.
Table 4. Effect of mycoversilin on leucyl-tRNA formation by leucyl-tRNA synthetase.

\begin{tabular}{ccc}
\hline $\begin{array}{c}\text { Mycoversilin } \\
(\mu \mathrm{g} / \mathrm{ml})\end{array}$ & cpm/mg protein & $\begin{array}{c}\text { Inhibition } \\
(\%)\end{array}$ \\
\hline 0 & 1,237 & - \\
10 & 900 & 27.2 \\
15 & 679 & 45.1 \\
25 & 529 & 57.2 \\
50 & 400 & 67.7 \\
100 & 322 & 73.1 \\
\hline
\end{tabular}

Incubation period: 20 minutes at $30^{\circ} \mathrm{C}$.

The mean of triplicate assay are presented.

The antibiotic slightly depressed incorporation of $\left[{ }^{14} \mathrm{C}\right]$ uracil into the TCA-insoluble fraction only at high concentrations.

\section{Effect of Mycoversilin on Protein Synthesis in Cell-free System}

Mycoversilin was found to inhibit polyU directed $\left[{ }^{14} \mathrm{C}\right]$ phenylalanine incorporation into protein very strongly. At growth inhibitory concentration $(15 \mu \mathrm{g} / \mathrm{ml})$ the antibiotic showed $59.2 \%$ inhibition of protein synthesis. However at the antibiotic concentrations $30 \mu \mathrm{g} / \mathrm{ml}$ and $60 \mu \mathrm{g} / \mathrm{ml}$ the inhibition was observed to the extent of $61.2 \%$ and $68.3 \%$ respectively (Table 2 ).

The data in Table 2 also reveals that omission of polyU, ATP or an energy generating system almost entirely eliminated $\left[{ }^{14} \mathrm{C}\right]$ phenylalanine incorporation into protein.

\section{Effect of Mycoversilin on Amino Acid Activation}

It appears from the results of Table 3 that mycoversilin did not significantly affect leucine dependent ATP- ${ }^{32} \mathrm{PP}_{\mathrm{i}}$ exchange at MIC. However, a significant inhibitory effect was observed only at a higher concentration, viz. $100 \mu \mathrm{g} / \mathrm{ml}$.

\section{Effect of Mycoversilin on Leucyl-tRNA Formation \\ by Leucyl-tRNA Synthetase}

It is observed from Table 4 that the synthesis of leucyl-tRNA formation by leucyl-tRNA synthetase was inhibited to the extent of $27.2 \%$ and $45.1 \%$ at subinhibitory $(10 \mu \mathrm{g} / \mathrm{ml})$ and minimum inhibitory $(15 \mu \mathrm{g} / \mathrm{ml})$ concentrations, respectively. On further increase in concentrations of the antibiotic, the degree of inhibition progressively increased, being $73.1 \%$ at $100 \mu \mathrm{g} / \mathrm{ml}$.

\section{Discussion}

Mycoversilin showed strong growth inhibition of filamentous fungus T. rubrum. The nature of antifungal action, fungistatic or fungicidal depend on the concentration of the antibiotic.

At low concentrations mycoversilin inhibited sporulation specifically but spore germination slightly whereas radial growth remained unaltered in the life cycle of T. rubrum. It has been reported that aabomycin A exhibited inhibitory effects on each of the stages of the growth cycle of Piricularia oryzae, spore germination being the most inhibited one in the growth cycle ${ }^{15)}$. Griseofulvin reduced the mycelial growth and spore germination of Cohliobolus miyabeanus ${ }^{16)}$. Chloramphenicol $(0.2 \mu \mathrm{g} / \mathrm{ml})$ inhibited spore germination of Anabaena doliolum when added during the first 24 hours $^{17)}$. The action of mycoversilin is therefore found to be different from these antibiotics with regards to its specific action on sporulation. 
Mycoversilin did not alter membrane permeability like polyene macrolides ${ }^{18)}$ or mycobacillin ${ }^{6,19)}$ and had no effect on endogenous or exogenous respiration of T. rubrum.

Mycoversilin was found to produce a preferential inhibition of protein synthesis to DNA synthesis, but it did not significantly affect RNA synthesis in the intact $T$. rubrum cells. In this respect mycoversilin resembles very strongly the antifungal antibiotics, cycloheximide ${ }^{20,21)}$, anisomycin ${ }^{22)}$ and sparsomycin $^{23,24)}$ in regard to the action on in vivo macromolecular synthesis.

The in vivo inhibitory action of mycoversilin on protein synthesis was further confirmed by its action in vitro in inhibiting polyU directed cell-free protein synthesis. In localising the exact site of action on in vitro protein synthesis it has been observed that the antibiotic inhibited not the aminoacylAMP formation but the aminoacyl-tRNA formation. In this respect it was similar to some but dissimilar to other antibiotics. The antibiotics nalidixic acid, oxolinic acid and novobiocin ${ }^{25)}$ inhibited both pyrophosphate exchange reaction and aminoacylation of specific tRNA in yeast, while sodium pseudomonate ${ }^{26)}$ inhibited only the pyrophosphate exchange reaction and had no action on isoleucyltRNA formation in Escherichia coli B. On the other hand the antibiotic furanomycin ${ }^{27}$, kasugamycin $^{28)}$, borrelidin ${ }^{20,30)}$ and granaticin ${ }^{31)}$ were shown to inhibit aminoacylation of specific tRNA in bacteria. Thus, there appears to be no report except the present one to our knowledge revealing the inhibition of aminoacylation of a specific tRNA by an antifungal agent. However, the action of mycoversilin, which specifically inhibits sporulation, remains yet to be explained.

Acknowledgments

This work was supported by grants from the Indian Council of Medical Research, New Delhi and from the University Grants Commission, New Delhi.

\section{References}

1) Samanta, A. K.; H. K. Kole, S. K. Goswami \& S. K. Bose: Mycoversilin, a new antifungal antibiotic from a mutant derivative of $A$. versicolor. Ind. J. Expt. Biol. 21: 577 578, 1983

2) Samanta, A. K. \& S. K. Bose: Mycoversilin, a new antifungal antibiotic. I. Fermentation, isolation and biological properties. J. Antibiotics 37: 728 732, 1984

3) Samanta, A. K.; S. K. Bose \& S. B. Mahato: Mycoversilin, a new antifungal antibiotic. II. Structure elucidation. J. Antibiotics 37: 733 737, 1984

4) Nene, Y. L.: Fungicides in Plant Disease Control. Vol. 1, pp. 286 287, Oxford and IBH Publication Co., New Delhi, 1971

5) Bose, S. K.: Significance of multiple pathways in adaptation. II. Inhibition of germination of $A$. niger as induced by exposure to phenylmethane dyes. Ind. J. Med. Res. 45: 249 253, 1957

6) Halder, A. \& S. K. Bose: Action of mycobacillin on filamentous fungi. Acta Microbiol. Polonica 2: $25 \sim 30,1970$

7) SINGH, K.; S. SUn \& C. VÉZINA: Rapamycin (AY-22,989), a new antifungal antibiotic. IV. Mechanism of action. J. Antibiotics 32: 630 645, 1979

8) Sugawara, S.: Mode of action of azalomycin F. Effect of azalomycin $F$ on Candida albicans. J. Antibiotics, Ser. A 20: 93 108, 1967

9) Lowry, O. H.; N. J. Rosebrough, A. L. Farr \& R. J. Randall: Protein measurement with the Folin phenol reagent. J. Biol. Chem. 193: 265 275, 1951

10) Hoagland, M. B.; M. L. Stephenson, J. F. Scott, L. L. Hecht \& P. C. Zamecnik: A soluble ribonucleic acid intermediate in protein synthesis. J. Biol. Chem. 231: $241 \sim 257,1958$

11) Staehelin, T. \& A. K. Falvey: Isolation of mammalian ribosomal subunits active in polypeptide synthesis. In Methods in Enzymology. Vol. XX. Ed. Moldave, K. \& L. Grossman, pp. 433 446, Academic Press, New York-London, 1971

12) Siekevitz, P.: Uptake of radioactive alanine in vitro into the proteins of rat liver fractions. J. Biol. Chem. 195: $549 \sim 565,1952$

13) Rотн, J. R. \& B. N. Ames: Histidine regulatory mutants in Salmonella typhimurium. II. Histidine regulatory mutants having altered histidyl-tRNA synthetase. J. Mol. Biol. 22: 325 334, 1966

14) Fangman, W. L. \& F. C. Neidhardt: Demonstration of an altered aminoacyl ribonucleic acid synthetase in a mutant of Escherichia coli. J. Biol. Chem. 239: 1839 1843, 1964 
15) Yamaguchi, I.; R. Taguchi, K. T. Huang \& T. Misato: Aabomycin A, a new antibiotic. II. Biological studies on aabomycin A. J. Antibiotics 22: 463 466, 1969

16) SRivastava, S. N. S.: In vitro effects of griseofulvin and sulphanilamide on Cochliobolus miyabeanus into et Kuribayashi. Curr. Sci. 35: 506 508, 1966

17) RAI, A. K.: Protein synthesis in germinating spores (akinetes) of Anabaena doliolum. Microbios. Lett. 13: $23 \sim 26,1980$

18) KINSKy, S. C.: Alterations in the permeability of Neurospora crassa due to polyene antibiotics. J. Bacteriol. 82: 889 897, 1961

19) BAnerJeE, N. \& S. K. Bose: Action of mycobacillin on cell wall permeability of a sensitive strain of Candida albicans. In Intern. Symp. on Mechanism of Action of Fungicides and Antibiotics. pp. 107 113, Reinherdesbrunn, Akademie-Verlag-Berlin, 1967

20) Shepherd, C. J.: Inhibition of protein and nucleic acid synthesis in Aspergillus nidulans. J. Gen. Microbiol. 18: iv v, 1958

21) KerRidge, D.: The effect of actidione and other antifungal agents on nucleic acids and protein synthesis in Saccharomyces carlsbergensis. J. Gen. Microbiol. 19: $497 \sim 506,1958$

22) Grollman, A. P.: Inhibitors of protein biosynthesis. J. Biol. Chem. 242: 3226 3233, 1967

23) Goldberg, I. H. \& K. Mitsugi: Sparsomycin, an inhibitor of aminoacyl transfer to polypeptide. Biochem. Biophys. Res. Commun. 23: 453 459, 1966

24) Colombo, B.; L. Felicetti \& C. Baglloni: Inhibition of protein synthesis in reticulocytes by antibiotics. I. Effects on polysome. Biochim. Biophys. Acta 119: 109 119, 1966

25) Wright, H. T.; K. C. Nurse \& D. J. Goldstein: Nalidixic acid, oxolinic acid and novobiocin inhibit yeast glycyl and leucyl-tRNA synthetases. Science 213: 455 456, 1981

26) Hughes, J. \& G. Mellows: Interaction of pseudomonic acid A with Escherichia coli B isoleucyl-tRNA synthetase. Biochem. J. 191: 209 219, 1980

27) TANAKA, K.; M. TAMAKi \& S. Watanabe: Effect of furanomycin on the synthesis of isoleucyl-tRNA. Biochim. Biophys. Acta 195: 244 245, 1969

28) Loftfield, R. B.: Inhibitors of amino acid activation. In Metabolic Inhibitors. Ed. HochSTER, R. M.; M. Kates \& J. H. QuAstel, pp. $107 \sim 130$, Academic Press, New York-London, 1973

29) Nass, G.; K. Poralla \& H. Z̈̈Hner: Effect of the antibiotic borrelidin on the regulation of threonine biosynthetic enzymes in E. coli. Biochem. Biophys. Res. Commun. 34: 84 91, 1969

30) Poralla, K. \& H. Zähner: Metabolic products of microorganisms. LXII. The inhibition of the attachment of threonine to sRNA in a cell-free system and of the synthesis of protein and nucleic acids in the cell by the antibiotic borrelidin. Arch. Mikrobiol. 61: 143 153, 1968

31) Ogilvie, A.; K. Wiebauer \& W. Kersten: Inhibition of leucyl-transfer ribonucleic acid synthetase in Bacillus subtilis by granaticin. Biochem. J. 152: 511 515, 1975 